\title{
Geologic carbon sources may confound ecosystem carbon balance estimates: Evidence from a semiarid steppe in the southeast of Spain
}

\author{
A. Rey, ${ }^{1,2}$ G. Etiope, ${ }^{2,3}$ L. Belelli-Marchesini, ${ }^{4,5}$ D. Papale, ${ }^{4}$ and R. Valentini ${ }^{4,6}$ \\ Received 22 February 2012; revised 16 July 2012; accepted 4 August 2012; published 27 September 2012.
}

[1] At a semiarid steppe site located in the SE of Spain, relatively large $\mathrm{CO}_{2}$ emissions were measured that could not be attributed to the ecosystem activity alone. Since the study site was located in a tectonically active area, it was hypothesized that a part of the measured $\mathrm{CO}_{2}$ was of geologic origin. This investigation included a survey of soil $\mathrm{CO}_{2}$ efflux, together with carbon isotope analyses of the $\mathrm{CO}_{2}$ in the soil atmosphere, soil $\mathrm{CO}_{2}$ efflux (i.e., Keeling plots), groundwater and local thermal springs. These measurements confirmed the hypothesis of degassing from geologic sources. In areas with local faults and ancient volcanic structures, soil $\mathrm{CO}_{2}$ efflux rates were significantly higher (i.e., up to 6.3 and $1.4 \mu \mathrm{mol} \mathrm{CO} \mathrm{m}^{-2} \mathrm{~s}^{-1}$ ) than measurements in a comparable site that was some distance from fault sites (means of 1.0 and $0.43 \mu \mathrm{mol} \mathrm{CO} \mathrm{CO}^{-2} \mathrm{~s}^{-1}$ in March and June, respectively). The $\mathrm{CO}_{2}$ concentration in the soil atmosphere at the eddy covariance site reached $0.14 \% \mathrm{v} / \mathrm{v}$ at $0.70 \mathrm{~m}$ soil depth with a ${ }^{13} \mathrm{C}$-enriched isotopic composition $\left(\delta^{13} \mathrm{C}\right.$ from $-10.2 \%$ to $-16.6 \%$ ), consistent with the isotopic composition of the soil $\mathrm{CO}_{2}$ efflux estimated by Keeling plots (i.e., $-16.6 \%$ ). ${ }^{13} \mathrm{C}$-enriched $\mathrm{CO}_{2}$ also occurred in local aquifers, and there was evidence of degassing from deep crust and mantle at regional scale by the helium isotopic ratio in spring waters located about $30 \mathrm{~km}(\mathrm{R} / \mathrm{Ra}: 0.12)$ and $200 \mathrm{~km}(\mathrm{R} / \mathrm{Ra}: 0.95) \mathrm{NW}$ of the eddy covariance site. This study highlights the importance of considering $\mathrm{CO}_{2}$ sources of geologic origin when assessing the net ecosystem carbon balance of sites that may possibly be affected by circulation of such $\mathrm{CO}_{2}$-rich fluids.

Citation: Rey, A., G. Etiope, L. Belelli-Marchesini, D. Papale, and R. Valentini (2012), Geologic carbon sources may confound ecosystem carbon balance estimates: Evidence from a semiarid steppe in the southeast of Spain, J. Geophys. Res., 117, G03034, doi:10.1029/2012JG001991.

\section{Introduction}

[2] As a consequence of increasing concern about the impact of climate change on functioning of ecosystems, there has recently been considerable interest in understanding the variables that control carbon cycling, particularly in terrestrial ecosystems [Le Quéré et al., 2009]. As a result, substantial methodological advances have been made, increasing confidence in our estimates of the contributions of terrestrial

\footnotetext{
${ }^{1}$ Museo Nacional de Ciencias Naturales (MNCN), Spanish National Research Council (CSIC), Madrid, Spain.

${ }^{2}$ Istituto Nazionale di Geofisica e Vulcanologia, Rome, Italy.

${ }^{3}$ Faculty of Environmental Science and Engineering, Babes-Bolyai University, Cluj-Napoca, Romania.

${ }^{4}$ Dipartimento per l'Innovazione nei Sistemi Biologici, Agroalimentari e Forestali (DIBAF), University of Tuscia, Viterbo, Italy.

${ }^{5}$ Department of Earth Sciences, Free University, Amsterdam, Netherlands.

${ }^{6}$ Euro-Mediterranean Center for Climate Change (CMCC), Lecce, Italy.

Corresponding author: A. Rey, Museo Nacional de Ciencias Naturales (MNCN), Spanish National Research Council (CSIC), Serrano 115, E-28006, Madrid, Spain. (Harey@mncn.csic.es)

(C)2012. American Geophysical Union. All Rights Reserved. 0148-0227/12/2012JG001991
}

ecosystems to the global carbon balance [Ciais et al., 2008; Le Quéré et al., 2009; Beer et al., 2010]. As a result, extensive data sets of fluxes of carbon dioxide $\left(\mathrm{CO}_{2}\right)$ and methane $\left(\mathrm{CH}_{4}\right)$ from a range of ecosystems are now available [e.g., Batjes and Bridges, 1994; Bonan, 1995; Law et al., 2002; U.S. Environmental Protection Agency (EPA), 2010, 2012].

[3] However, the majority of studies presuppose that virtually all the exchanges of $\mathrm{CO}_{2}$ and $\mathrm{CH}_{4}$ between terrestrial ecosystems and the atmosphere are the consequences of biologic processes resulting from photosynthesis, plant respiration, microbial activity and animal respiration. This approach may be inappropriate in situations where ecosystems may release gases of geologic origin, i.e., gases that have originated in the subsoil rocks and subterranean structures, ranging from the lithosphere to the Earth's mantle [see review by Kerrick, 2001].

[4] It is well known that $\mathrm{CO}_{2}$ of geologic origin is released to the atmosphere not only by volcanoes, but also diffusely from the soil in geothermal areas or over tectonic faults, independently of the surface ecosystem. Geologic faults generally act as pathways for migration to the Earth's surface of gas originating by deep (typically $>1 \mathrm{~km}$ ) thermometamorphism of carbonate rocks or mantle degassing 
Table 1. Main Characteristics of the Balsablanca Eddy Covariance Site [After Rey et al., 2011]

\begin{tabular}{lc}
\hline \multicolumn{1}{c}{ Characteristic } & Description \\
\hline Longitude & $2^{\circ} 11^{\prime} 58^{\prime \prime} \mathrm{W}$ \\
Latitude & $36^{\circ} 56^{\prime} 30^{\prime \prime} \mathrm{N}$ \\
Altitude $(\mathrm{m})$ & 208 \\
Orientation & $\mathrm{NW}$ \\
Slope $(\%)$ & $2-6$ \\
Average annual temperature $\left({ }^{\circ} \mathrm{C}\right)$ & 18 \\
Maximun summer temperature $\left({ }^{\circ} \mathrm{C}\right)$ & 34 \\
Average annual rainfall $(\mathrm{mm})$ & 200 \\
Mean annual atmospheric pressure & 99 \\
$\quad(\mathrm{kPa})$ & 69.3 \\
Mean annual relative humidity $(\%)$ & \\
Vegetation & Steppe alpha grass \\
Soil type ${ }^{\mathrm{a}}$ & Sandy loam \\
Soil texture class & $0-30$ \\
Soil depth $(\mathrm{cm})$ & 16.1 \\
Clay $(\%)$ & 22.8 \\
Silt $(\%)$ & 61.1 \\
Sand $(\%)$ & 1.25 \\
Bulk density $\left(\mathrm{g}\right.$ cm ${ }^{-3}$ ) & 21.9 \\
Mean annual soil temperature $\left({ }^{\circ} \mathrm{C}\right)$ & 13.8 \\
Mean annual soil water content $(\%)$ & \\
\hline
\end{tabular}

${ }^{\mathrm{a}}$ IUSS Working Group WRB [2006].

[e.g., Barnes et al., 1978; Grace and van Gardingen, 1997; Chiodini et al., 1999; Etiope, 1999; Kerrick, 2001; Mörner and Etiope, 2002]. This deep and widespread geologic $\mathrm{CO}_{2}$ should not be confused with that produced locally by weathering (dissolution) of shallow calcareous rocks, which may be involved in the carbon balance of ecosystems located on karstic environments [e.g., Kowalski et al., 2008; SerranoOrtiz et al., 2009]. Geologic $\mathrm{CO}_{2}$ has been found to occur extensively in soils throughout wide areas characterized by grassland or woodland ecosystems in Europe and USA, even without evidence at the Earth surface of geothermal manifestations and far from volcanic systems [e.g., Gregory and Durrance, 1985; Hinkle, 1990; Chiodini et al., 1999; Etiope, 1999; Klusman et al., 2000; Lewicki and Brantley, 2000; Klusman, 2005]. These "hidden" geologic sources may release several types of endogenous gases (e.g., $\mathrm{CO}_{2}, \mathrm{CH}_{4}, \mathrm{~N}_{2}, \mathrm{He}$ ) to the atmosphere, some of which can contribute to the net ecosystem carbon exchange of terrestrial ecosystems.

[5] While $\mathrm{CO}_{2}$ is the most important carbon-bearing gas in geothermal-volcanic areas, geologic $\mathrm{CH}_{4}$ emissions may be relevant in sedimentary basins with petroleum production [Etiope and Klusman, 2010]. Indeed, geo- $\mathrm{CH}_{4}$ sources are extremely important at global scale, representing the second largest natural $\mathrm{CH}_{4}$ source (at least $60 \mathrm{Tg} \mathrm{y}^{-1}$ ) [Etiope, 2012] after wetlands, and about $10 \%$ of the total $\mathrm{CH}_{4}$ emissions [Etiope et al., 2008; EPA, 2010]. Earth's degassing is considered to be a relatively minor $\mathrm{CO}_{2}$ source globally (probably in the order of $600-1000 \mathrm{Tg} \mathrm{CO}_{2} \mathrm{y}^{-1}$ i.e., $\sim 2 \%{ }^{-}$ $3 \%$ of the anthropogenic sources and $10 \%$ of the carbon source resulting from deforestation and land-use change, and about $18 \%$ of the current terrestrial sink [Mörner and Etiope, 2002; Pan et al., 2011]. Both geo- $\mathrm{CH}_{4}$ and geo- $\mathrm{CO}_{2}$ may, however, affect surface ecosystem fluxes on wide areas and confound local scale carbon budgets attributed to biologic activity leading to inaccurate estimates. An example of such a phenomenon involving $\mathrm{CH}_{4}$ may be represented by emission of geologic gas in agricultural rice paddies in Japan which can be confused with biologic gas emissions [Etiope et al., 2011]. An example involving geo- $\mathrm{CO}_{2}$ is presented in this paper.

[6] A recent study carried out with the aim of quantifying the carbon, water and energy ecosystem fluxes using the eddy covariance technique in a natural grassland ecosystem in southeastern Spain reported relatively large $\mathrm{CO}_{2}$ emissions over the dry period that could not be attributed to the vegetation activity alone [Rey et al., 2012]. Anomalous ecosystem $\mathrm{CO}_{2}$ emissions and interannual patterns were observed at the Balsablanca eddy covariance site that suggested the presence of other nonbiologic carbon sources. As a consequence, we could not apply standard partitioning techniques to derive photosynthesis and respiration [Reichstein et al., 2005; Lasslop et al., 2010]. After examination of the study area, we concluded that the site of Balsablanca is located in a geothermal basin very close to a tectonic fault system of regional importance (the Carboneras Fault). This then led to the hypothesis of a geologic contribution to the $\mathrm{CO}_{2}$ efflux from the soil [Rey et al., 2012].

[7] Here, we verify this hypothesis through an investigation that includes a soil $\mathrm{CO}_{2}$ efflux survey, carbon isotopic analyses of $\mathrm{CO}_{2}$ in the soil atmosphere (at the eddy covariance site), aquifers and natural water springs located approximately $30 \mathrm{~km}$ southwest of Balsablanca (part of the same geologic system). Isotopic composition of helium $\left({ }^{3} \mathrm{He} /{ }^{4} \mathrm{He}\right)$, a tracer of deep-origin gas, was analyzed in a natural water spring and compared with literature data of other springs in the same geologic region (onshore Alboran Basin). In addition, Keeling plots, a widely used method to determine the carbon isotope composition of ecosystem respiration [Pataki et al., 2003], were used to assess the stable carbon isotopic ratio of soil $\mathrm{CO}_{2}$ efflux. All data confirm the presence in the soil of $\mathrm{CO}_{2}$ of geologic origin, which may confound assessments of the local ecosystem carbon balance that can be attributed to ecosystem activity.

\section{Material and Methods}

\subsection{Site Description}

[8] The study site of Balsablanca is located in the Cabo de Gata Natural Park, in the province of Almería (Andalusía), in southeastern Spain $\left(36^{\circ} 56^{\prime} 26.0^{\prime \prime} \mathrm{N}, 2^{\circ} 01^{\prime} 58.8^{\prime \prime} \mathrm{W}\right)$. The climate in this area is subtropical, dry, and semiarid with a mean annual precipitation of $250 \mathrm{~mm}$ and a mean annual temperature of approximately $18^{\circ} \mathrm{C}$ (Table 1 ). It is characterized by prolonged summer droughts (from May to September), and infrequent and random rainfall events when the vegetation is mostly inactive [Rey et al., 2011]. Annual potential evapotranspiration is approximately $1390 \mathrm{~mm}$ (nearby meteorological station of Níjar). Precipitation mostly occurs in spring and autumn with strong interannual variation and random events.

[9] The site is equipped with meteorological and eddy covariance towers designed to measure the exchange of carbon, water, and energy between the ecosystem and the atmosphere (part of the CARBOEUROPE and FLUXNET networks of flux sites since May 2006). The ecosystem is a natural grassland characterized by open vegetation-free areas (65\% ground coverage), dominated by Stipa tenacissima The dominant soils are classified as Lithic leptosols (calcaric) [IUSS Working Group WRB, 2006], and are thin, of variable depth (on average $10 \mathrm{~cm}$ ), alkaline $(\mathrm{pH}>8)$, saturated 


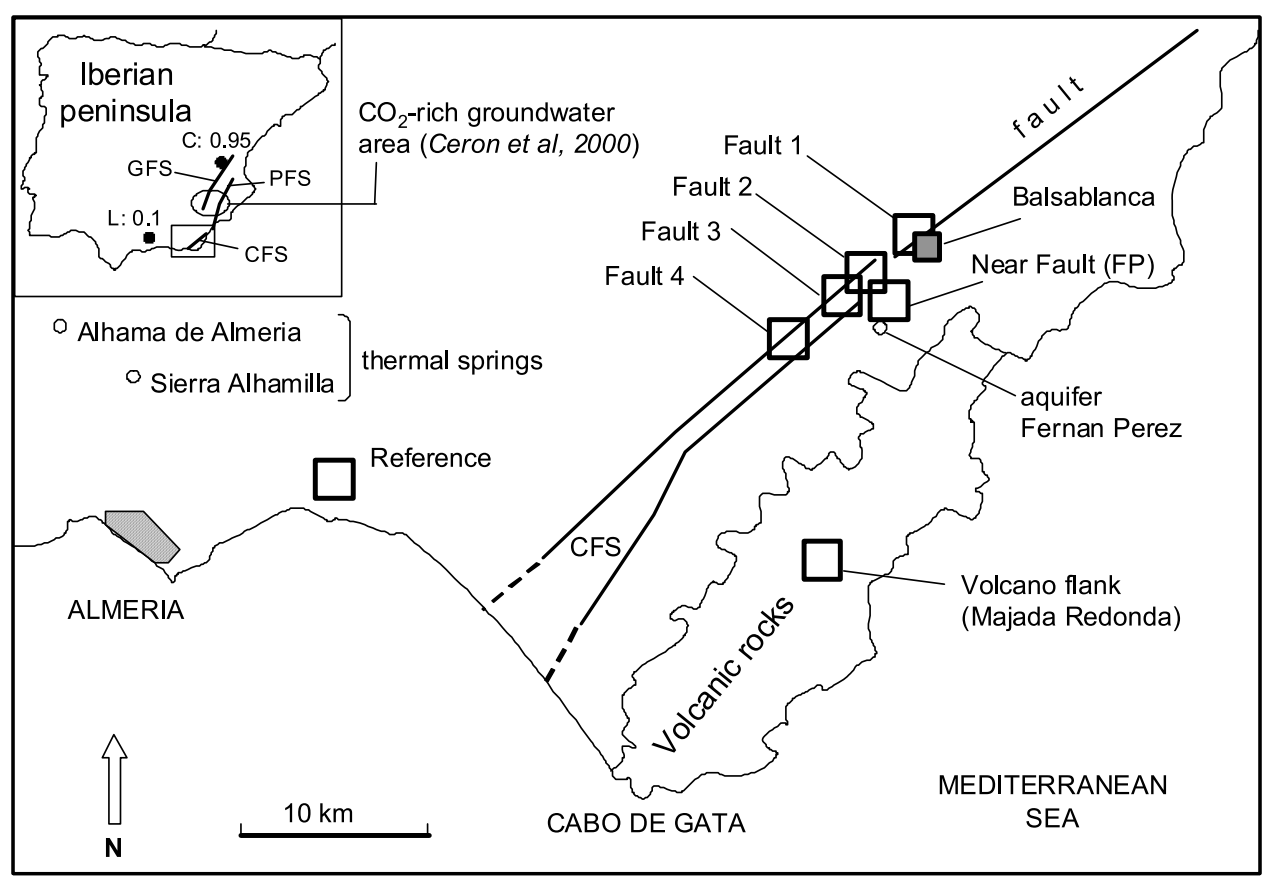

Figure 1. Location map of soil $\mathrm{CO}_{2}$ efflux measurement sites (squares) and groundwater sampling in thermal springs and aquifer (small circles). The small Iberia map shows the location of degassing sites west and northeast of the investigated area (rectangle): L: Lanjarón, with helium isotopic ratio R/Ra: 0.1; C: Cofrentes, with R/Ra: 0.95 [Pérez et al., 1996]. GFS: Guedalentín Fault System; PFS: Palomares Fault System [Cerón et al., 2000]. The $\mathrm{CO}_{2}$-rich groundwater area refers to the sites with ${ }^{13} \mathrm{C}$-enriched carbon waters similar to those of the aquifer near Balsablanca (see text). Fault and volcanic rock locations are after Aguirre et al. [2006].

in carbonates with a moderate stone content and with frequent rock outcrops (additional details of the site are given by Rey et al. 2011, 2012].

[10] Geologically, the site of Balsablanca is in the Betic Cordilleras, at the western margin of the Cabo de Gata volcanic complex of Miocene age (last volcanic episode is about 7.5 Ma old), formed as a consequence of extensional processes related to the development of the Alboran Basin after the Alpine collision between the African and Eurasian plates [Sanz de Galdeano, 1990; Martín et al., 2009]. The Balsablanca site is located exactly over the Carboneras Fault System (CFS; Figure 1), one of the three main regional tectonic faults of southeast Spain (the other two are the Palomares, and Guadalentín sinistral strike-slip faults) producing a shear zone with crustal thinning ("rifting") and regional seismicity [Sanz de Galdeano et al., 1995]. The area represents a rift basin related to the formation of other European similar rifts, like the Rhine basin in Germany and the Rhone and Algero-Provençal basins in France [Sanz de Galdeano, 1990]. The CFS produced a large-scale deformation zone with relevant fracturation of the Miocene sedimentary and volcanic rocks. The adjacent ancient volcano hosted hydrothermal systems with several fluid emission points, including fumaroles (Cinto, Los Tolles), today extinct, located at about $13 \mathrm{~km}$ southwest of Balsablanca. The contemporary geothermal condition of the Cabo de Gata area is evidenced by the relatively high heat flow, $84 \mathrm{~mW} \mathrm{~m}^{-2}$ (against an average of $65 \mathrm{~mW} \mathrm{~m}^{-2}$ for the Iberian mainland) measured in a well about $20 \mathrm{~km}$ southwest of Balsablanca [Fernàndez et al., 1998].
[11] The stratigraphic rock sequence in the Balsablanca area is formed by outcrops of old Quaternary alluvial fans, calcareous conglomerates and sands (Pliocene), marine carbonates (Messinian and Tortonian) and volcanic rocks (Tortonian) at about $80-100 \mathrm{~m}$ below the ground, overlying the Betic carbonatic Mesozoic basement [Martín et al., 2009].

\subsection{Soil $\mathrm{CO}_{2}$ Efflux Survey}

[12] We postulated that soil $\mathrm{CO}_{2}$ efflux rates were likely to be higher or anomalous in areas associated with geologic gas exhalation. We therefore tested whether we could detect higher soil $\mathrm{CO}_{2}$ efflux rates associated with proximity to the fault and an ancient volcano area and compared those rates with rates measured in a reference "background" location far from the volcano fault system, but with similar vegetation (alpha grass) and soil substrate (calcaric Lithic leptosol), as shown in Figure 1.

[13] Because soil chamber methods provide a flux measurement at small spatial scale, numerous measurements were made to characterize both spatial trends and variability of fluxes at both sites. The so-called reference background site, is an area supposedly not affected by any geothermal activity in the ground, where we would expect the measured soil $\mathrm{CO}_{2}$ efflux rates to be solely the result of biologic activity or soil respiration. A total of 200 soil $\mathrm{CO}_{2}$ efflux measurements were made by static closed-chamber methods on two occasions: in March (when the vegetation is still active) and in June 2011 (the vegetation is mostly dormant and soil respiration is strongly limited by water shortage [Rey et al., 2011]). The measurements were made in five 
different locations along the Carboneras fault, at the top of an ancient volcano (the Majada Redonda volcanic caldera), at the eddy covariance tower site of Balsablanca, and at the reference background site. Four sites along the Carboneras fault (Faults 1-4) refer to alpha grass ecosystems located exactly in correspondence with the main Carboneras fault line, based on published geologic maps, satellite images and field recognition of morphological tectonic scarps and outcrops. The "Near Fault" site (close to Fernán Pérez village) is along a minor morphological scarp of probable tectonic origin, $500 \mathrm{~m}$ south of the main fault line (in correspondence with Fault 2 site).

[14] All measurements were done on similar alpha grass ecosystems but on bare soil patches between plants (at least $50 \mathrm{~cm}$ from a plant), and on the same vegetation type as at the Balsablanca site (Stipa tenacissima). In March, a $10 \mathrm{dm}^{3}$ closed chamber was connected to West Systems flux meter with Licor $\mathrm{CO}_{2}$ analyzer (West Systems, Pontedera, Italy) [Etiope et al., 2011] and in June a $3.5 \mathrm{dm}^{3}$ closed chamber connected to a soil respiration system EGM-4 (PP Systems, Hitchin, UK) was used. We intended to use the same instrument in both occasions but it was not possible because of a malfunction problem with the EGM-4 instrument at the first sampling period. However, both sets of equipment were calibrated against each other for consistency and soil $\mathrm{CO}_{2}$ efflux rates corrected accordingly using a regression between both estimates $\left(n=10, R^{2}=0.90\right)$. All measurements were made between $10.00 \mathrm{~h}$ and $14.00 \mathrm{~h}$ during several days to avoid diurnal fluctuations and to obtain a range of environmental conditions: growing season in March soon after a rainy period (soil volumetric water content above $5 \%$ and air temperature below $20^{\circ} \mathrm{C}$ and thus with the vegetation still active) and a dry period in June (soil volumetric water content below $5 \%$ and air temperature above $20^{\circ} \mathrm{C}$, with the vegetation mostly dormant, as shown by Rey et al. [2011]). The exact location of each measurement point was recorded with a GPS. Soil temperature at $3.5 \mathrm{~cm}$ depth was measured with a digital thermometer and soil volumetric water content with a portable theta probe (ML2x, Devices Ltd., Cambridge, $\mathrm{UK}$ ) at the time of each soil $\mathrm{CO}_{2}$ efflux measurement. To test whether soil $\mathrm{CO}_{2}$ efflux rates measured in both periods differed between sites, a single analysis of variance at a probability of 5\% was done (PROC ANOVA) using SAS statistical software 9.2. (SAS Software, SAS Institute, Cary, N.C., USA).

\subsection{Keeling Plots}

[15] In order to determine the carbon isotopic composition of soil $\mathrm{CO}_{2}$ efflux we used the Keeling plot approach as described by Pataki et al. [2003]. This approach uses a twocomponent mixing model that consists of the carbon isotope ratio of $\mathrm{CO}_{2}\left(\delta^{13} \mathrm{C}\right)$ released and that in the background atmosphere. The intercept of a linear regression of $\delta^{13} \mathrm{C}$ of atmospheric $\mathrm{CO}_{2}$ versus $1 /\left[\mathrm{CO}_{2}\right]$ (where $\left[\mathrm{CO}_{2}\right]$ is the mole fraction of $\mathrm{CO}_{2}$ ) provides an estimate of the $\delta^{13} \mathrm{C}$ of the soil $\mathrm{CO}_{2}$ efflux (CR).

[16] For this purpose, we designed 15 clear opaque chambers with soil collars made of PVC $(20 \mathrm{~cm}$ in diameter and $10 \mathrm{~cm}$ high). The soil collars were inserted $3 \mathrm{~cm}$ into the ground one day before each measurement campaign. The chambers were designed with a sealed T-connector at the top to allow air sampling during each measurement campaign.
The lids were placed at time 0 and a first sample of air from a chamber was taken with a $50 \mathrm{~cm}^{3}$ LUER LOK syringe with an insulin needle; the sample was injected under slight pressure into a $20 \mathrm{~cm}^{3}$ vial previously left under vacuum. Five samples from each chamber were taken every $15 \mathrm{~min}$, so that all five samples per chamber were taken in $75 \mathrm{~min}$. Chamber dimensions and measuring time interval were estimated based on previous soil $\mathrm{CO}_{2}$ efflux rates at the site to ensure a large enough $\mathrm{CO}_{2}$ gradient $(75 \mathrm{ppmv}$, as advised by Pataki et al. [2003]) and linearity between $\left[\mathrm{CO}_{2}\right]$ and $\delta^{13} \mathrm{C}$ [Takahashi and Liang, 2007]. The glass vials were sealed with rubber stop-cocks and a hot glue gun until analyses. Septum-capped vials have been tested and proven to be suitable for air transport [Glatzel and Well, 2008]. The vials, including vials with standards, were taken to the laboratory in the Centro Nazionale delle Ricerche at Porano (Italy) and analyzed for $\mathrm{CO}_{2}$ concentration and $\delta^{13} \mathrm{C}$ with a Gas Chromatography-Isotopic Ratio Mass Spectrometry (ISOPRIME mod. JB287, GV Instruments, Manchester, UK) connected to a multiflow Gilson 222XL auto-sampler. We determined the evolution rate and isotopic composition $\left[\delta^{13} \mathrm{C}(\% \mathrm{o}): \delta^{13} \mathrm{C}=1,000\left[\left(\mathrm{R}_{\text {sample }}-\mathrm{R}_{\text {standard }}\right) / \mathrm{R}_{\text {standard }}\right](\%)\right.$, where: $\mathrm{R}={ }^{13} \mathrm{C} /{ }^{12} \mathrm{C}$ ] of the $\mathrm{CO}_{2}$ from the soil sample. The $\mathrm{CO}_{2}$ evolution rate and $\delta^{13} \mathrm{C}$ of the evolved $\mathrm{CO}_{2}$ were calculated from the change over time in $\mathrm{CO}_{2}$ concentration and $\delta^{13} \mathrm{C}$ of the $\mathrm{CO}_{2}$ in the sampled vials.

[17] Samples were taken on the 3-4 June 2011. We placed the soil chambers in the most representative soil covers at the site [Rey et al., 2011] laid out in five plots each one with three soil cover types: under plant, biologic soil crust and bare soil. Soil temperature and soil volumetric water content measured at $3.5 \mathrm{~cm}$ was recorded at the time of each measurement adjacent to each chamber as described above. To ensure further that vial usage, overpressurization and storage did not influence the results; we carefully evaluated each step (including transport from the site in Spain to the lab in Italy) by comparing all measurements with a standard of known concentration and carbon isotopic composition in the mass spectrometer (standard deviation less than 0.02\%o). Since there were no statistically significant differences between the regression lines of individual replicates $(P<0.05)$, we fitted all measured points for each soil cover type to a single regression line in order to calculate the intercept for each soil cover-i.e., the ${ }^{13} \mathrm{C}$ of the $\mathrm{CO}_{2}$ released under each soil cover type - and compared the regression lines for any significant differences among the slopes and intercepts (general linear models (GLM) in SAS statistical software).

\subsection{Sampling and Analyses of Soil-Air and Gas Dissolved in Aquifers and Springs}

[18] Seven soil-gas samples (0.70 m deep) were collected at two points (P1 and $\mathrm{P} 2)$ at the Balsablanca site by inserting into the soil a metallic probe $(3 \mathrm{~cm}$ in diameter and $100 \mathrm{~cm}$ long), that was sealed at the top and left to equilibrate with the soil atmosphere for a day. A syringe and silicon tube equipped with a T-valve, were used to reduce atmospheric air contamination during sampling. The first sample at P1 was stored in a $150 \mathrm{~cm}^{3}$ glass tube equipped with two stopcocks, for molecular compositional analyses. The other six samples (three in P1 and three in P2) were stored in $12 \mathrm{~cm}^{3}$ evacuated vials for $\mathrm{CO}_{2}$ and $\delta^{13} \mathrm{C}_{\mathrm{CO} 2}$ analyses. 


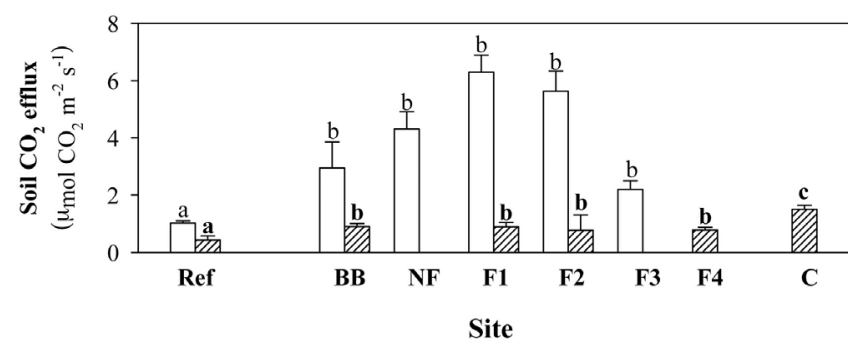

Figure 2. Bar plot of soil $\mathrm{CO}_{2}$ efflux rates measured at the different locations along the Carboneras fault (F1, F2, F3, F4), near fault (NF), at the eddy covariance tower site (BB), at an ancient volcano caldera (C) and a reference site (Ref) measured in March (white area) and June (striped area). Bars represent the mean $( \pm 1 \mathrm{SE})$ of all measuring points at each site $(n=15-20)$. Bars with different letters $(\mathrm{a}, \mathrm{b}, \mathrm{c})$ of the same period are statistically significantly different (ANOVA, $P<0.05$ ).

[19] Additionally, three water samples were collected from a public well drilled into the main aquifer of the Fernán Pérez and Balsablanca area. The well reaches a depth of $140 \mathrm{~m}$ corresponding to carbonate/volcanic rocks $\left(36^{\circ} 54^{\prime} 50.46^{\prime \prime} \mathrm{N}\right.$, $12^{\circ} 03^{\prime} 59.73^{\prime \prime} \mathrm{W}$; see Figure 1). $250 \mathrm{~cm}^{3}$ water samples were taken and sealed with a rubber stopper and kept in a fridge until analysis.

[20] Four water samples were also collected at two thermal springs, located about $30 \mathrm{~km}$ southwest of Balsablanca, at Sierra Alhamilla $\left(36^{\circ} 58^{\prime} 57.6^{\prime \prime} \mathrm{N}, 2^{\circ} 23.8^{\prime} 32.99^{\prime \prime} \mathrm{W}\right)$ and Alhama de Almería ( $\left.36^{\circ} 57^{\prime} 26.73^{\prime \prime} \mathrm{N}, 2^{\circ} 34^{\prime} 12.27^{\prime \prime} \mathrm{W}\right)$. Water was stored in $250 \mathrm{~cm}^{3}$ glass bottles. $\mathrm{CO}_{2}, \delta^{13} \mathrm{C}_{\mathrm{CO} 2}$ and $\delta^{13} \mathrm{C}_{\text {TDIC }}$ (Total Dissolved Inorganic Carbon) analyses in six soil-gas and five water samples (two from the springs and three from the aquifer) were done by the Stable Isotope Facility of the University of California, Davis. $\delta^{13} \mathrm{C}_{\mathrm{CO} 2}$ was measured using a ThermoScientific PreCon-GasBench system interfaced to a Thermo Scientific Delta V Plus isotope ratio mass spectrometer (Thermo Scientific, Bremen, Germany). Two laboratory standards, calibrated against NIST 8545, were analyzed every 10 samples. Long-term standard deviation was $0.02 \%$. $\delta^{13} \mathrm{C}_{\mathrm{TDIC}}$ was analyzed using a Surveyor HPLC coupled to a ThermoFinnigan Delta Plus Advantage isotope ratio mass spectrometer (Thermo Scientific, Bremen, Germany) through a LC Isolink interface. Two laboratory standards (lithium carbonate dissolved in degassed deionised water and a deep seawater reference sample, both calibrated against NIST 8545), were analyzed every 10 samples.

[21] Compositional analyses of soil-air, including $\mathrm{N}_{2}, \mathrm{O}_{2}$, $\mathrm{CO}_{2}, \mathrm{CH}_{4}, \mathrm{CO}, \mathrm{He}$, and isotopic composition of helium in a water spring (Sierra Alhamilla), were done by the Fluid Chemistry Laboratory of Istituto Nazionale di Geofisica e Vulcanologia of Palermo. The dissolved gas was extracted in the laboratory after attainment of equilibrium (at constant temperature) between water samples and a known volume of host, high-purity gas (argon), injected into the sampling bottle (as described by Capasso and Inguaggiato [1998]). The analytical determinations were carried out using a Perkin Elmer 8500 gas chromatograph equipped with a double detector (TCD-FID), with argon as the carrier gas. Helium isotope analyses were done on gas fractions extracted following the same procedure as for the gas chromatography.
The samples were then purified following standard procedures [see Sano and Wakita, 1988]. The isotopic analyses of the purified helium fraction were performed by a static vacuum mass spectrometer (GVI5400TFT) that allows for simultaneous detection of ${ }^{3} \mathrm{He}$ and ${ }^{4} \mathrm{He}$-ion beams, thereby keeping the ${ }^{3} \mathrm{He} /{ }^{4} \mathrm{He}$ error of measurement to very low values. Typical uncertainties in the range of low- ${ }^{3} \mathrm{He}$ samples are within 5\%. Helium isotopic ratio is expressed in the $\mathrm{R} / \mathrm{Ra}$ notation, which is the ${ }^{3} \mathrm{He} /{ }^{4} \mathrm{He}$ ratio between sample and atmospheric air $\left(=1.410^{-6}\right)$; the ratio has been corrected for atmospheric contamination (based on the ${ }^{4} \mathrm{He} /{ }^{20} \mathrm{Ne}$ ratio) [Hilton, 1996].

\section{Results and Discussion}

\subsection{Soil $\mathrm{CO}_{2}$ Efflux}

[22] Environmental conditions differed between the two periods, with optimal conditions for plant and soil activity in March, whereas conditions were most likely minimal during the dry period in June [Rey et al., 2011]. Soil $\mathrm{CO}_{2}$ efflux rates were always higher in March than in June, including measurements on bare soil (where biologic activity is minimal compared to the heterotrophic and autotrophic respiration in patches beneath plants with high fine root density and soil organic matter content). However, the tendency for higher soil $\mathrm{CO}_{2}$ efflux rates on sites associated with proximity to the fault and ancient volcano was found in both measurement periods. Rates of soil $\mathrm{CO}_{2}$ efflux measured at all the fault sites and at the volcanic caldera were systematically higher than the rates measured at the reference site, with rates ranging from 6.3 to $2.2 \mu \mathrm{mol} \mathrm{CO}_{2} \mathrm{~m}^{-2} \mathrm{~s}^{-1}$ and from 1.4 to $0.77 \mu \mathrm{mol} \mathrm{CO} \mathrm{m}^{-2} \mathrm{~s}^{-1}$ in March (when fault sites were significantly different from the reference site, $P<0.05$ ) and June (when fault sites were significantly different from the reference site, $P<0.001$ ), respectively (Figure 2). In June, the highest mean soil $\mathrm{CO}_{2}$ efflux was recorded at the ancient caldera. At the reference site, soil $\mathrm{CO}_{2}$ efflux rates ranged from 1.0 to $0.4 \mu \mathrm{mol} \mathrm{CO} \mathrm{Cm}^{-2} \mathrm{~s}^{-1}$ in March and June, respectively. At the Balsablanca site, soil $\mathrm{CO}_{2}$ efflux rates were intermediate with an average value of 3.0 and $0.9 \mu \mathrm{mol} \mathrm{CO} \mathrm{m}^{-2} \mathrm{~s}^{-1}$ in March and June, respectively. The measured soil $\mathrm{CO}_{2}$ efflux rates at Balsablanca are consistent with those measured previously on bare soil at the site [Rey et al., 2011] but higher than expected based on rates typically occurring on bare soils under similar environmental conditions in semiarid grasslands [e.g., Conant et al., 2000; Maestre and Cortina, 2006; Carbone et al., 2008]. In particular, soil $\mathrm{CO}_{2}$ efflux rates measured along the fault are higher than soil respiration rates reported in semiarid grasslands, although still low compared to the mean biologic $\mathrm{CO}_{2}$ efflux from soils, which ranges from 0.2 to $21 \mathrm{~g} \mathrm{C} \mathrm{m}^{-2} \mathrm{~d}^{-1}$ [e.g., Raich and Tufekcioglu, 2000; Bond-Lamberty and Thomson, 2010]. Since wind is the main driver of the short-term net ecosystem carbon balance (NECB) at the eddy covariance site of Balsablanca where $\mathrm{CO}_{2}$ effluxes of up to $15 \mu \mathrm{mol} \mathrm{CO} \mathrm{C}_{2}^{-2} \mathrm{~s}^{-1}$ were measured over the dry period in concurrence with strong winds [Rey et al., 2012], it is likely that closed static chambers may preclude some of the $\mathrm{CO}_{2}$ from deep origins to be released, so that soil $\mathrm{CO}_{2}$ efflux rates were underestimated. However, we were primarily concerned with the relative comparison between sites and would, therefore, still expect the observed differences 


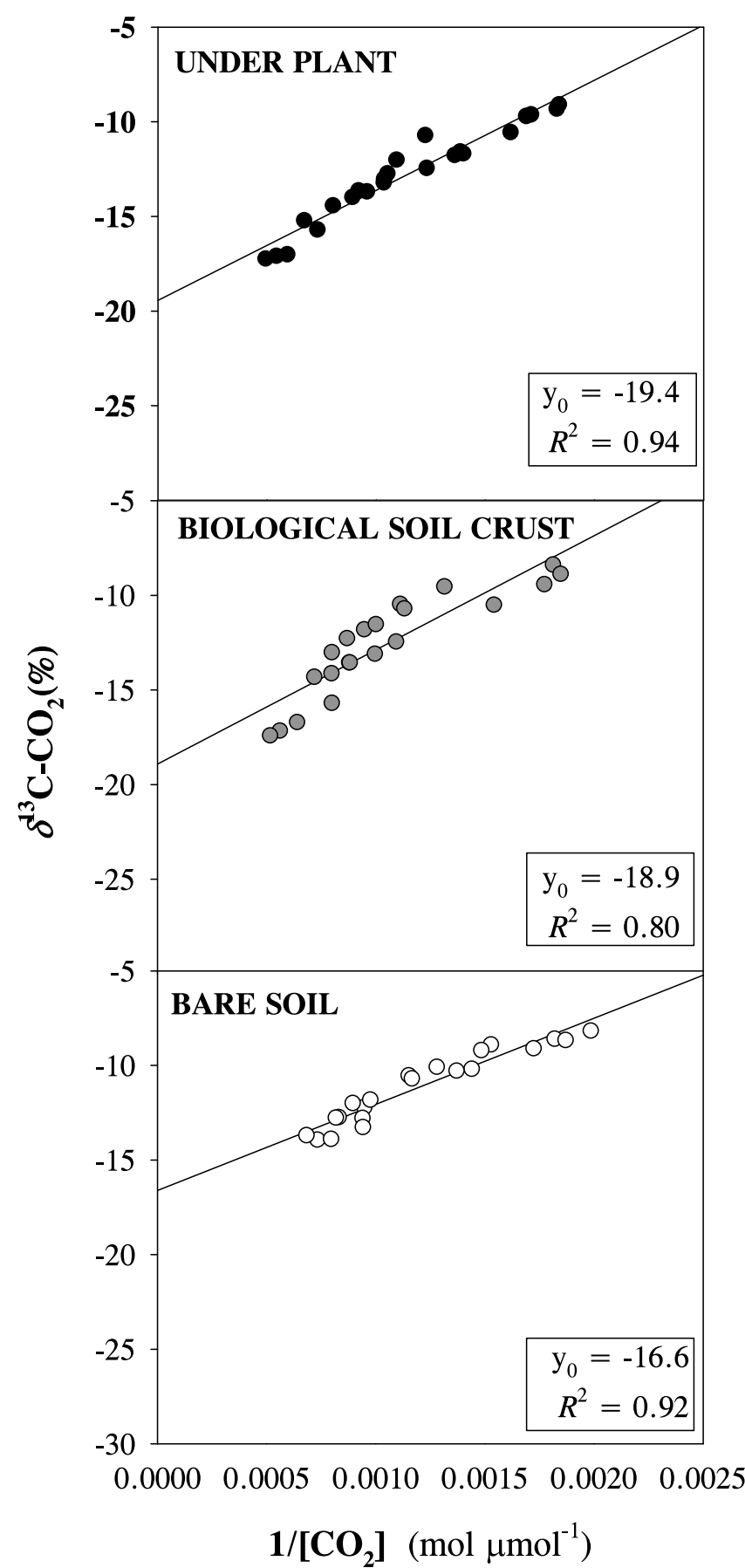

Figure 3. Keeling plots of soil $\mathrm{CO}_{2}$ efflux at three soil covers: under Stipa plants, biologic soil crusts and bare soil $(n=5)$ in June 2011. Samples were collected from each chamber with at least 75 ppmv $\mathrm{CO}_{2}$ change between successive samples over a 75-min period. Measurements were made at noon, when soil temperatures averaged $25^{\circ} \mathrm{C}$. The Keeling plot calculations are given in the text. Isotope ratios are plotted against the inverse of $\mathrm{CO}_{2}$ concentration.

between different locations. Surface winds and atmospheric dispersion, in particular, are very effective at diluting $\mathrm{CO}_{2}$ micro-seepage fluxes [Oldenburg et al., 2003]. Since most of the $\mathrm{CO}_{2}$ produced by biologic activity, particularly in the very shallow soils (Table 1), is generated close to the soil surface [Rey et al., 2008] the geologic $\mathrm{CO}_{2}$ component coming from deeper layers would be the most underestimated component when using closed chamber methods.

[23] Since all measurements were made on bare soil far from any plant and under very dry conditions, particularly over the dry season, we would expect minimal biologic contribution to the measured soil $\mathrm{CO}_{2}$ effluxes. Indeed, we observed relatively low rates at the reference steppe site compared to other ecosystems [Bond-Lamberty and Thomson, 2010]. Instead, soil $\mathrm{CO}_{2}$ efflux measured within fault areas were larger than expected based on previous long-term soil $\mathrm{CO}_{2}$ efflux records measured under similar environmental conditions at the Balsablanca site [Rey et al., 2011] and those measured in other ecosystems in the area located far from the fault and ancient volcanic caldera [Oyonarte et al., 2012]. Although the absolute values may be low compared to other ecosystems, and even more compared to other active geothermal areas where large soil $\mathrm{CO}_{2}$ emissions have been reported [e.g., Werner and Brantley, 2003; Chiodini et al., 2008], the relative contribution to carbon emissions in this ecosystem may be considerable as indicated by the relatively large $\mathrm{CO}_{2}$ emissions measured during dry periods by eddy covariance at the Balsablanca site [Rey et al., 2012]. Indeed, in a follow-up study in which we have partitioned net ecosystem carbon balance into biologic and geologic components, it has been estimated that approximately half of the $\mathrm{CO}_{2}$ emitted comes from geologic sources (A. Rey et al., Partitioning estimates of net ecosystem carbon balance into biological and geological sources in a semiarid steppe ecosystem in the southeast of Spain, manuscript in preparation, 2012).

\section{2. $\delta^{13} \mathrm{C}$ of Soil $\mathrm{CO}_{2}$ Efflux}

[24] Based on the mixing model approach described in the Material and Methods section [Pataki et al., 2003], we calculated an averaged $\delta^{13} \mathrm{CR}$ (of the three soil covers at the eddy covariance site) to be $-18.3 \%$ o $( \pm 0.51)$. Within each soil type, variability was low and replicated measurements of $\delta^{13} \mathrm{CR}$-soil were statistically indistinguishable so all replicates were used to fit a single regression line for each soil cover (Figure 3). In contrast, the $\delta^{13} \mathrm{CR}$-soil of $\mathrm{CO}_{2}$ efflux from soils differed among soil cover types as expected $(P<0.001)$. In June 2011 , the $\delta^{13} \mathrm{CR}$-soil was -19.4 $( \pm 0.39),-18.9( \pm 0.76)$ and $-16.6( \pm 0.40) \%$ for soil $\mathrm{CO}_{2}$ efflux measured under plant, biologic soil crust and bare soil, respectively (Figure 3 ). The intercept was significantly different among soil covers $(P<0.001)$. This pattern of $\delta{ }^{13} \mathrm{CR}$-soil increasing with plant proximity is reasonable given that the contribution of depleted carbon from organic sources is expected to increase with proximity to plants (most roots and soil organic matter are found below plants) [see Rey et al., 2011]. However, all values confirmed the presence of a nonbiologic component of $\mathrm{CO}_{2}$ in the respired $\mathrm{CO}_{2}$. The $\delta^{13} \mathrm{C}$ value of present atmospheric $\mathrm{CO}_{2}$ is close to $-8 \%$ [Bowling et al., 2008]. The $\delta^{13} \mathrm{C}$ composition of $\mathrm{CO}_{2}$ respired from plant roots is isotopically depleted relative to the atmosphere as a result of isotopic fractionation during photosynthesis and will have an isotopic composition between -24 to $-38 \%$ in $\mathrm{C}_{3}$ plants [Pataki et al., 2003]. When most of the $\mathrm{CO}_{2}$ released comes from biologic sources, one would expect the carbon isotopic signal of the respired soil $\mathrm{CO}_{2}$ to be close to that of the plant material [Hungate 
Table 2. $\mathrm{CO}_{2}$ Concentration and $\delta^{13} \mathrm{C}$ Values $\left(\mathrm{CO}_{2}\right.$ or $\left.\mathrm{T}_{\mathrm{DIC}}\right)$ in Soil-Air $(0.7 \mathrm{~m}$ Deep $)$ at the Balsablanca Eddy Covariance Tower Site, in the Local Aquifer of Fernán Pérez and in the Closest Thermal Springs (Including a Water Sample With Helium Concentration and Isotopic Ratio)

\begin{tabular}{lcccccc}
\hline \multicolumn{1}{c}{ Site } & Type & $\mathrm{CO}_{2}(\mathrm{ppmv})$ & $\delta^{13} \mathrm{C}_{\mathrm{CO} 2}\left(\%, \mathrm{VPDB}^{\mathrm{a}}\right)$ & $\delta^{13} \mathrm{C}_{\mathrm{TDIC}}(\%$, VPDB$)$ & $\mathrm{TDIC}(\mathrm{mM})$ & $\mathrm{He}(\mathrm{ppmv})$ \\
\hline Balsablanca P1 $(n=1)$ & Soil-air & 1400 & -10.2 & & \\
Balsablanca P1 $(n=3)$ & Soil-air & $555-588$ & $-16.6 \pm 0.19$ & & \\
Balsablanca P2 $(n=3)$ & Soil-air & $436-521$ & $-14.5 \pm 0.01$ & & \\
Fernán Pérez $(n=3)$ & Aquifer & & $-14.1 \pm 0.29^{\mathrm{b}}$ & $-6.1 \pm 0.3$ & $1.80 \pm 0.36$ & \\
Alhama de Almeria spring & Spring & 25038 & -12.1 & & 91 \\
Sierra Alhamilla spring & Spring & 19595 & -16.4 & & 0.12 \\
\hline
\end{tabular}

${ }^{a}$ VPDB: Vienna Pee Dee Belemnite standard.

${ }^{\mathrm{b}}$ Recalculated values based on the procedure by Mook et al. [1974].

et al., 1997; Werner and Gessler, 2011]. Foliar $\delta^{13} \mathrm{C}$ values of Stipa tenacissima measured in the same area are on average -24\%o [Maestre and Cortina, 2006; Armas et al., 2009]. Instead, when other carbon sources are present, the isotopic signal of the $\mathrm{CO}_{2}$ released should be ${ }^{13} \mathrm{C}$ enriched. Note that as a result of fractionation during diffusion (ca. -4.4\%o) [Amundson et al., 1998], the soil respired $\mathrm{CO}_{2}$ is depleted in $\delta^{13} \mathrm{C}$ relative to the soil $\mathrm{CO}_{2}$ (Table 2). This is not apparent under steady state conditions, in which case soil derived $\mathrm{CO}_{2}$ becomes enriched by $+4.4 \%$ and the $\delta^{13} \mathrm{C}$ of soil-respired $\mathrm{CO}_{2}$ approaches that of the source organic material [Dörr and Münich, 1987; Cerling et al., 1991].

[25] In most cases, respiration processes predominantly operate in the soil zone. Therefore, the isotopic composition of $\mathrm{CO}_{2}$ beneath the soil should be less affected by isotopic composition of the soil gases. In particular, numerous studies have reported $\mathrm{CO}_{2}$ carbon isotopic (i.e., $\delta^{13} \mathrm{C}-\mathrm{CO}_{2}$ ) compositions down vertical soil gas profiles, demonstrating that $\mathrm{CO}_{2}$ undergoes significant isotopic fractionation during its diffusive pathway through the soil atmosphere both in volcanic-hydrothermal degassing areas [Camarda et al., 2007], where a deep $\mathrm{CO}_{2}$ source is present, and in vegetated areas [Amundson et al., 1998; Cerling et al., 1991], where the soil $\mathrm{CO}_{2}$ flux is the result of biogenic sources alone. The $\delta^{13} \mathrm{C}$ values of this $\mathrm{CO}_{2}$ will be similar to that of the organic source mass and may not vary significantly from values of the soil-respired $\mathrm{CO}_{2}$.

\section{3. $\mathrm{CO}_{2}$ in Soil-Air at Balsablanca}

[26] The concentration of $\mathrm{CO}_{2}$ detected at a depth of $0.70 \mathrm{~m}$ in the soil at Balsablanca ranged from 436 to $1400 \mathrm{ppmv}$ (Table 2). The 1400 ppmv $\mathrm{CO}_{2}$ sample had $77.8 \% \mathrm{~N}_{2}, 19.1 \%$ $\mathrm{O}_{2}, 2$ ppmv $\mathrm{CH}_{4}$ and 5 ppmv He. $\delta^{13} \mathrm{C}_{\mathrm{CO} 2}$ ranged from $-10.2 \%$ (in the 1400 ppmv sample) to $-16.1 \%$ (555 ppmv), with an average value of $-14 \%$. This is approximately $6 \%$ lower than atmospheric $\mathrm{CO}_{2}$ and 10 to 24\%o higher than typical biologic $\mathrm{CO}_{2}$ released in soil respiration [Pataki et al., 2003]. The $\delta^{13} \mathrm{C}$ signature of $\mathrm{CO}_{2}$ derived from geothermal sources (e.g., magmatic or metamorphic sources) typically ranges from $-2 \%$ to $-6 \%$ [Faure, 1986] and will mix with $\mathrm{CO}_{2}$ derived from $\mathrm{C}_{3}$ plants. The 1400 ppmv concentration is considerable given that the sample was taken from a depth with no mineral soil [Rey et al., 2011]. This value is, however, rather low for areas with deep $\mathrm{CO}_{2}$ degassing [e.g., Etiope, 1999; Etiope et al., 1999; Williams-Jones et al., 2000]. However, taken together with the $\delta^{13} \mathrm{C}$ of soil air, which was similar to that of soil water and the thermal spring nearby, this value further suggests that some $\mathrm{CO}_{2}$ occurring in the soil is inorganic, derived from deep carbon sources. These may include $\mathrm{CO}_{2}$ produced by thermo-metamorphism of carbonate rocks and mantle material (typically producing $\delta^{13} \mathrm{C}$ of about $0 \%$ and $-6.5 \%$ respectively [Sano and Marty, 1995]. Values of $\delta^{13} \mathrm{C}$ similar to those of Balsablanca are known to occur in soils affected by deep-origin $\mathrm{CO}_{2}$ degassing in several countries, e.g., in central Italy [Klusman et al., 2000]. In particular, values in the range of $-17 \%$ to $-5 \%$ have been considered to represent mixing between biologic $\mathrm{CO}_{2}(<-17 \%)$ and hydrothermal $\mathrm{CO}_{2}(>-5 \%)$ [Chiodini et al., 2008]. The measured Balsablanca values of $\delta^{13} \mathrm{C}_{\mathrm{CO} 2}$ are in agreement with values that have been derived from Keeling plots, as reported in Section 3.2.

\section{4. $\mathrm{CO}_{2}$ Dissolved in Groundwater and Helium at Sierra Alhamilla}

[27] The average $\delta^{13} \mathrm{C}_{\mathrm{TDIC}}$ value of three water samples of the local aquifer was $-6.1 \%$. This is similar to the values of between $-8.1 \%$ and $-3.8 \%$, reported for groundwater located in the Guadalentín Fault System (GFS), which is a rift basin similar to the study area, about $35 \mathrm{~km}$ north of Balsablanca [Cerón et al., 2000] (Figure 1). It is known that in aquifers affected by even low $\mathrm{CO}_{2}$ degassing, $\mathrm{CO}_{2}$ should be dominantly present in the aqueous phase as dissolved inorganic carbon (TDIC, i.e., $\mathrm{CO}_{2}(\mathrm{aq}), \mathrm{H}_{2} \mathrm{CO}_{2}, \mathrm{HCO}_{3}^{-}$, and $\mathrm{CO}_{3}^{-2}$ ). With the increasing degassing of $\mathrm{CO}_{2}$, DIC also increases.

[28] The values of $\delta^{13} \mathrm{C}-\mathrm{CO}_{2}(-14.1 \%)$ recalculated on the basis of equilibrium constants of the dissolved carbon species (with isotope enrichment factors for the $\mathrm{CO}_{2}$ gas$\mathrm{HCO}_{3}$ and the $\mathrm{CO}_{2}$ gas- $\mathrm{CO}_{2}$ aq. systems [Mook et al., 1974]) are similar to those measured in the soil-air at Balsablanca and lie within the range of those measured in the thermal springs. The two thermal springs located about 30 and $40 \mathrm{~km}$ west of Balsablanca in fact showed $\delta^{13} \mathrm{C}_{\mathrm{CO} 2}$ values of $-12.1 \%$ and $-16.4 \%$, with concentrations of $\mathrm{CO}_{2}$ in the extracted gas-phase of up to $25000 \mathrm{ppmv}$. The $\delta^{13} \mathrm{C}_{\mathrm{CO} 2}$ values are consistent with those of the soil and the aquifers, and this suggests that mixing between the biologic, meteorologic and geologic carbon pools is a widespread and general process in the area.

[29] The helium isotopic ratio $(\mathrm{R} / \mathrm{Ra})$ measured in the gas extracted from the Sierra Alhamilla spring was 0.12 . This is associated to a ${ }^{4} \mathrm{He} /{ }^{20} \mathrm{Ne}$ ratio of about 8 , which is about 28 times higher than the atmospheric ratio, and thus indicates negligible atmospheric contamination.

[30] The R/Ra versus $\delta^{13} \mathrm{C}_{\mathrm{CO} 2}$ plot (Figure $4 \mathrm{a}$ ), traditionally used to estimate crustal versus mantle components of $\mathrm{CO}_{2}$ 

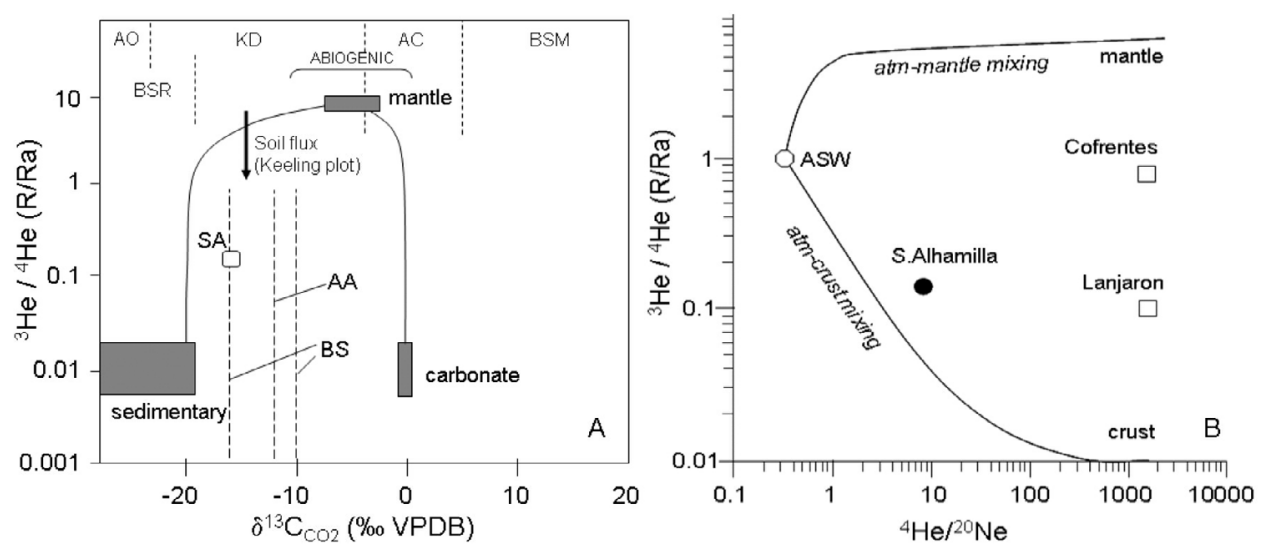

Figure 4. He isotopic ratio $\mathrm{R} / \mathrm{Ra}$ versus $\delta^{13} \mathrm{C}_{\mathrm{CO} 2}$ (A) and versus ${ }^{4} \mathrm{He} /{ }^{20} \mathrm{Ne}(\mathrm{B})$. SA: Sierra Alhamilla spring; AA: Alhama de Almería spring; BS: Balsablanca soil. $\mathrm{CO}_{2}$ isotope zonation modified after Etiope et al. [2011]. AO, aerobic hydrocarbon oxidation; KD, kerogen decarboxylation; AC, alteration of marine carbonates; BSM, biodegradation and secondary methanogenesis; BSR, biologic soil respiration; ASW, air-saturated water. Cofrentes and Lanjarón springs data are from Pérez et al. [1996]. Vertical arrow indicates the $\delta^{13} \mathrm{C}_{\mathrm{CO} 2}$ value derived by the Keeling plot of Figure 3 .

[Sano and Marty, 1995], showed that the Sierra Alhamilla spring is close to the mixing line between sedimentary and mantle end-members. The stable carbon isotopic composition of $\mathrm{CO}_{2}$ exhaled from the soil derived by the Keeling plots is within the range of the values measured in the soil-air. However, all the values are higher than the range expected for biologic soil respiration (BSR). The helium isotopic ratio then suggests a deep gas source, with a dominant crustal component and minor (about 1\%) mantle signal (Figure 4b). A similar $\mathrm{R} / \mathrm{Ra}$ value, 0.1 , has been reported for $\mathrm{CO}_{2}$-rich waters at Lanjarón (Granada), about $100 \mathrm{~km}$ southwest of Balsablanca (Figure 1) [Pérez et al., 1996]. Higher values, 0.95, were found at Cofrentes [Pérez et al., 1996], which is $200 \mathrm{~km}$ northeast of Balsablanca. This last value suggests that about $10 \%$ of helium has a mantle origin. The increase of the mantle signal from south to north, passing through the Balsablanca area, reflects a younger and more active (seismic) tectonic activity toward the northern sector of the southeast Spain rift [Pérez et al., 1996]. It is known, then, that $\mathrm{CO}_{2}$ degassing may increase or decrease in relation to seismicity [e.g., Bräuer et al., 2003], and consequently the geo- $\mathrm{CO}_{2}$ component in the Balsablanca soil may change over time, thus reflecting the tectonic activity of CFS.

\section{Conclusions and Recommendations for Future Work}

[31] The hypothesis proposed initially by Rey et al. [2012], regarding the occurrence of endogenous $\mathrm{CO}_{2}$ released from beneath the steppe ecosystem under study, is supported here by a combination of soil $\mathrm{CO}_{2}$ efflux measurements and carbon isotopic analyses of soil air and groundwater.

[32] In correspondence with local faults and ancient volcanic structures, soil $\mathrm{CO}_{2}$ efflux rates were higher than those measured far from fault sites regardless of the measuring period (Figure 5); the soil $\mathrm{CO}_{2}$ efflux at the eddy covariance site, accidentally positioned over a large fault system, reached concentrations of $0.14 \% \mathrm{v} / \mathrm{v}$ at $0.70 \mathrm{~m}$ depth with a ${ }^{13} \mathrm{C}$-enriched isotopic composition $\left(\delta^{13} \mathrm{C}\right.$ from $-10.2 \%$ to
$-16.6 \%$ ), consistent with the values derived from Keeling plots (i.e., $-16.6 \%$ in bare soil). ${ }^{13} \mathrm{C}$-enriched carbon also occurred in local aquifers, and signals of degassing from deep crust and even mantle were detected at regional scale by the helium isotopic ratio in thermal spring waters. The geologic origin of $\mathrm{CO}_{2}$, is probably not then related to weathering processes acting on relatively shallow calcareous rocks or subterranean cavity ventilation (as hypothesized by Kowalski et al. [2008] and Serrano-Ortiz et al. [2009] for some karstic areas), but is most likely related to deeper, regional geothermal fluid circulation systems connected to the ancient volcanism of Cabo de Gata. As also suggested by the relatively high geothermal heat flow and the helium isotopic composition in springs, the relevant $\mathrm{CO}_{2}$ production mechanism may be similar to that of typical geothermal $\mathrm{CO}_{2}$-degassing areas, widespread on all continents (i.e., thermo-metamorphism of deep carbonate rocks and degassing from the mantle) [e.g., Mörner and Etiope, 2002; Chiodini et al., 2008].

[33] 1) In an earlier study of the steppe ecosystem [Rey et al., 2012], it was estimated that the NECB ranged from

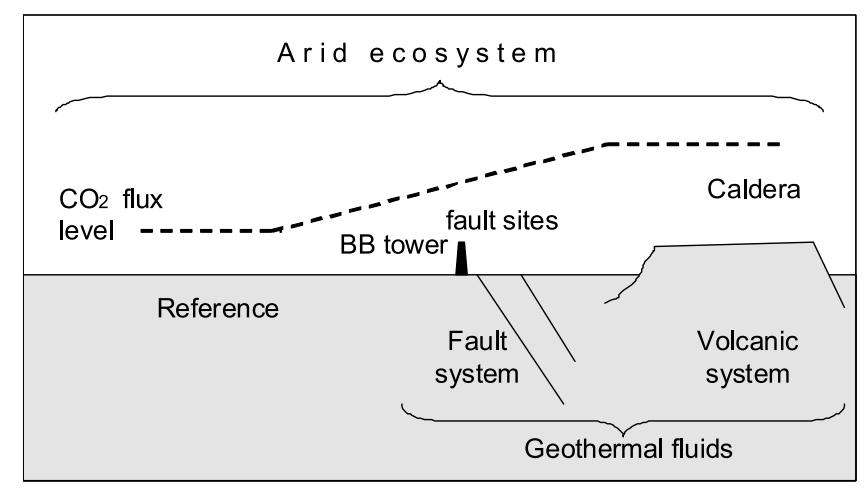

Figure 5. Schematic model of geo- $\mathrm{CO}_{2} / \mathrm{soil}-\mathrm{CO}_{2}$ mixing in relation to geologic factors of the Cabo de Gata area. 
65.7 to $143.6 \mathrm{~g} \mathrm{C} \mathrm{m}^{-2} \mathrm{y}^{-1}$, suggesting that the steppe ecosystem could be an appreciably large carbon source to the atmosphere. The present investigation has shown that even in areas where emissions of geologic $\mathrm{CO}_{2}$ are not immediately evident, the contribution of "hidden" endogenous sources of $\mathrm{CO}_{2}$ may be of major importance to the ecosystem carbon budget.

[34] 2) Given the low content of soil organic matter and small standing biomass at the site, an initial interpretation was that the ecosystem under study was highly unsustainable. The present investigation has clarified that a significant part of the carbon released did not result from ecosystem activity but was derived from geologic sources.

[35] 3) When ecosystems are on geologically active or geothermal areas, additional sources of carbon do contribute negatively to the net ecosystem carbon balance and must be taken into account when estimating the net ecosystem carbon exchange with the atmosphere.

[36] 4) By not taking into account geologic $\mathrm{CO}_{2}$ sources, considerable errors in the estimates of the NECB attributed to vegetation activity may result. A further study aimed at separating the geologic from the biologic components of the $\mathrm{CO}_{2}$ released, has estimated an average contribution of geologic $\mathrm{CO}_{2}$ to the NECB of 55\% (Rey et al., manuscript in preparation, 2012).

[37] 5) At local ecosystem scale, an appropriate initial geologic site inspection is recommended in relation to carbon budget objectives. On national, continental and global scales, carbon emission data sets from geographic areas potentially affected by geologic gas releases should be the object of further examination.

[38] 6) Thus the FLUXNET community should be aware of geologic $\mathrm{CO}_{2}$ and $\mathrm{CH}_{4}$ carbon sources when planning field measurements and should take these into account when estimating the net ecosystem carbon balance of vegetation, particularly in tectonically active areas, but more widely when modeling regional, continental and global carbon budgets.

[39] Acknowledgments. We thank the bilateral national program Acciones Integradas, funded by the Ministries of Science and Technology of Spain and Italy. This study has been funded by the CARBOARID project (CGL2005-00563), Spain's Ministry of Environment (INIA project SUM2006-00018-C02-0), and the FP7 European project CARBOEXTREME. A.R. was granted a one-year fellowship by the Andalusian government to visit the University of Tuscia (Department of Forests and the Environment). The authors thank Mr. Spaccino, Dr. Gavrichkova and Prof. Brugnoli at CNR of Porano and Dr. Subke at Stirling University for help with carbon isotopic analyses, Dr. Castaldi at Napoli II University for help with chamber design, Dr. Italiano for the compositional and $\mathrm{He}$ and $\mathrm{CO}_{2}$ isotopic analyses performed at INGV Sezione di Palermo, and Mr. Rey for help with field sampling. We thank Prof. Jarvis for revising the manuscript and two anonymous reviewers and the Editor for useful comments.

\section{References}

Aguirre, J., A. B. Pérez-Muñoz, and I. M. Sánchez-Almazo (2006), Benthic foraminifer assemblages in the lower Pliocene deposits of the Almeria-Níjar Basin (SE Spain), Rev. Española Micropaleontol., 38, 411-428.

Amundson, R., L. Stern, T. Baisden, and Y. Wang (1998), The isotopic composition of soil and soil-respired $\mathrm{CO}_{2}$, Geoderma, 82, 83-114, doi:10.1016/ S0016-7061(97)00098-0.

Armas, C., Z. Kikvidze, and F. I. Pugnaire (2009), Abiotic conditions, neighbour interactions, and the distribution of Stipa tenacissima in a semiarid mountain range, J. Arid Environ., 73, 1084-1089, doi:10.1016/j.jaridenv. 2009.06.012.

Barnes, I., W. P. Irwin, and D. E. White (1978), Global distribution of carbondioxide discharges, and major zones of seismicity, scale 1:40,000,000. Water Resources Invest. WRI 78-39. U.S. Geol. Surv., Washington, DC.
Batjes, N. H., and E. M. Bridges (1994), Potential emissions of radiatively active gases from soil to atmosphere with special reference to methane: Development of a global database (WISE), J. Geophys. Res., 99, 16,479-16,489, doi:10.1029/93JD03278.

Beer, C., et al. (2010), Terrestrial Gross Carbon Dioxide Uptake: Global Distribution and Covariation with Climate, Science, 329, 834-838, doi:10.1126/science. 1184984 .

Bonan, G. B. (1995), Land-atmosphere $\mathrm{CO}_{2}$ exchange simulated by a land surface process model coupled to an atmospheric general circulation model, J. Geophys. Res., 100, 2817-2831, doi:10.1029/94JD02961.

Bond-Lamberty, B., and A. Thomson (2010), A global database of soil respiration data, Biogeosciences, 7, 1915-1926, doi:10.5194/bg-7-19152010.

Bowling, D. R., D. E. Pataki, and J. T. Randerson (2008), Carbon isotopes in terrestrial ecosystem pools and $\mathrm{CO}_{2}$ fluxes, New Phytol., 178, 24-40, doi:10.1111/j.1469-8137.2007.02342.x.

Bräuer, K., H. Kämpf, G. Strauch, and S. M. Weise (2003), Isotopic evidence $\left({ }^{3} \mathrm{He} /{ }^{4} \mathrm{He},{ }^{13} \mathrm{C}_{\mathrm{CO} 2}\right)$ of fluid-triggered intraplate seismicity, J. Geophys. Res., 108(B2), 2070, doi:10.1029/2002JB002077.

Camarda, M., S. De Gregorio, R. Favara, and S. Gurrieri (2007), Evaluation of carbon isotope fractionation of soil $\mathrm{CO}_{2}$ under an advective e diffusive regimen: A tool for computing the isotopic composition of unfractionated deep source, Geochim. Cosmochim. Acta, 71, 3016-3027, doi:10.1016/ j.gca.2007.04.002.

Capasso, G., and S. Inguaggiato (1998), A simple method for the determination of dissolved gases in natural waters. An application to thermal waters from Vulcano island, Appl. Geochem., 13, 631-642, doi:10.1016/S08832927(97)00109-1.

Carbone, M. S., G. C. Winston, and S. E. Trumbore (2008), Soil respiration in perennial grass and shrub ecosystems: Linking plant and microbial sources with environmental controls on seasonal and diel timescales, J. Geophys. Res., 113, G02022, doi:10.1029/2007JG000611.

Cerling, T. E., D. K. Solomon, J. Quade, and J. R. Bowman (1991), On the isotopic composition of carbon in soil carbon dioxide, Geochim. Cosmochim. Acta, 55, 3403-3405, doi:10.1016/0016-7037(91)90498-T.

Cerón, J. C., M. Martín-Vallejo, and L. García-Rossell (2000), $\mathrm{CO}_{2}$-rich thermomineral groundwater in the Betic Cordilleras, southeastern Spain: Genesis and tectonic implications, Hydrogeol. J., 8, 209-217, doi:10.1007/ s100400050239.

Chiodini, G., F. Frondini, D. M. Kerrick, J. Rogie, F. Parello, L. F. Peruzzi, and A. R. Zanzari (1999), Quantification of deep $\mathrm{CO}_{2}$ fluxes from Central Italy. Examples of carbon balance for regional aquifers and of soil diffuse degassing, Chem. Geol., 159, 205-222, doi:10.1016/S0009-2541(99) 00030-3.

Chiodini, G., S. Caliro, C. Cardellini, R. Avino, D. Granieri, and A. Schmidt (2008), Carbon isotopic composition of soil $\mathrm{CO}_{2}$ efflux, a powerful method to discriminate different sources feeding soil $\mathrm{CO}_{2}$ degassing in volcanic-17hydrothermal areas, Earth Planet. Sci. Lett., 274, 372-379, doi:10.1016/j.eps1.2008.07.051.

Ciais, P., et al. (2008), Carbon accumulation in European forests, Nat. Geosci., 1, 425-429, doi:10.1038/ngeo233.

Conant, R. T., J. M. Klopatek, and C. C. Klopatek (2000), Environmental factors controlling soil respiration in three semiarid ecosystems, Soil Sci. Soc. Am. J., 64, 383-390, doi:10.2136/sssaj2000.641383x.

Dörr, H., and K. O. Münich (1987), Annual variations in soil respiration in selected areas of the temperate zone, Tellus, 39B, 114-121, doi:10.1111/ j.1600-0889.1987.tb00276.x.

Etiope, G. (1999), Subsoil $\mathrm{CO}_{2}$, and $\mathrm{CH}_{4}$ and their advective transfer from faulted grassland to the atmosphere, J. Geophys. Res., 104, 16,889-16,894, doi:10.1029/1999JD900299.

Etiope, G. (2012), Methane uncovered, Nat. Geosci., 5, 373-374, doi:10.1038/ ngeo1483.

Etiope, G., and R. W. Klusman (2010), Microseepage in drylands: Flux and implications in the global atmospheric source/sink budget of methane, Global Planet. Change, 72, 265-274, doi:10.1016/j.gloplacha.2010.01. 002 .

Etiope, G., P. Beneduce, M. Calcara, P. Favalia, F. Frugonia, M. Schiattarell, and G. Smriglio (1999), Structural pattern and $\mathrm{CO}_{2}-\mathrm{CH}_{4}$ degassing of Ustica Island, Southern Tyrrhenian basin, J. Volcanol. Geotherm. Res., 88, 291-304, doi:10.1016/S0377-0273(99)00010-4.

Etiope, G., K. R. Lassey, R. W. Klusman, and E. Boschi (2008), Reappraisal of the fossil methane budget and related emission from geologic sources, Geophys. Res. Lett., 35, L09307, doi:10.1029/2008GL033623.

Etiope, G., R. Nakada, K. Tanaka, and N. Yoshida (2011), Gas seepage from Tokamachi mud volcanoes, onshore Niigata Basin (Japan): Origin, post-genetic alterations and $\mathrm{CH}_{4}-\mathrm{CO}_{2}$ fluxes, Appl. Geochem., 26, 348-359, doi:10.1016/j.apgeochem.2010.12.008.

Faure, G. (1986), Principles of Isotope Geochemistry, 475 pp., John Wiley, New York. 
Fernàndez, M., I. Marzán, A. Correia, and E. Ramalho (1998), Heat flow, heat production, and lithospheric thermal regime in the Iberian Peninsula, Tectonophysics, 291, 29-53, doi:10.1016/S0040-1951(98)00029-8.

Glatzel, S., and R. Well (2008), Evaluation of septum-capped vials for storage of gas samples during air transport, Environ. Monit. Assess., 136, 307-311, doi:10.1007/s10661-007-9686-2.

Grace, J., and P. R. van Gardingen (1997), Sites of naturally elevated carbon dioxide, in Plant Responses to Elevated $\mathrm{CO}_{2}$. Evidence from Natural Springs, edited by A. Raschi et al., pp. 1-6, Cambridge Univ. Press, Cambridge, U. K., doi:10.1017/CBO9780511565236.002.

Gregory, R. G., and E. M. Durrance (1985), Helium, carbon dioxide and oxygen soil gases: Small-scale variations over fractured ground, J. Geochem. Explor., 24, 29-49, doi:10.1016/0375-6742(85)90003-2.

Hilton, D. R. (1996), The helium and carbon isotope systematics of a continental geothermal system: Results from monitoring studies at Long Valley caldera (California, USA), Chem. Geol., 127, 269-295, doi:10.1016/0009-2541(95)00134-4.

Hinkle, M. E. (1990), Factors affecting concentrations of helium and carbon dioxide in soil gases, in Geochemistry of Gaseous Elements and Compounds, edited by E. M. Durrance et al., pp. 421-448, Theophrastus, Athens.

Hungate, B. A., E. A. Holland, R. B. Jackson, F. S. Chapin III, H. A Mooney, and C. B. Field (1997), On the fate of carbon in grasslands under carbon dioxide enrichment, Nature, 388, 576-579, doi:10.1038/ 41550 .

IUSS Working Group WRB (2006), World reference base for soil resources 2006: A framework for international classification, correlation and communication, World Soil Resour. Rep. 103, 128 pp., Food and Agric. Organ. of the U. N., Rome.

Kerrick, D. M. (2001), Present and past non-anthropogenic $\mathrm{CO}_{2}$ degassing from the solid Earth, Rev. Geophys., 39, 565-585, doi:10.1029/2001RG000105.

Klusman, R. W. (2005), Baseline studies of surface gas exchange and soilgas composition in preparation for $\mathrm{CO}_{2}$ sequestration research: Teapot Dome, Wyoming, Am. Assoc. Pet. Geol. Bull., 89, 981-1003.

Klusman, R. W., J. N. Moore, and M. P. LeRoy (2000), Potential for surface gas flux measurements in exploration and surface evaluation of geothermal resources, Geothermics, 29, 637-670, doi:10.1016/S0375-6505 (00)00036-5.

Kowalski, A. S., P. Serrano-Ortiz, I. A. Janssens, S. Sánchez-Moral, S. Cuezva, F. Domingo, A. Were, and L. Alados-Arboledas (2008), Can flux tower research neglect geochemical $\mathrm{CO}_{2}$ exchange?, Agric. For. Meteorol., 148, 1045-1054, doi:10.1016/j.agrformet.2008.02.004.

Lasslop, G., M. Reichstein, D. Papale, A. D. Richardson, A. Arneth, A. Barr, P. C. Stoy, and G. Wohlfahrt (2010), Separation of net ecosystem exchange into assimilation and respiration using a light response curve approach: Critical issues and global evaluation, Global Change Biol., 16, 187-208, doi:10.1111/j.1365-2486.2009.02041.x.

Law, B. E., et al. (2002), Environmental controls over carbon dioxide and water vapour exchange of terrestrial vegetation, Agric. For. Meteorol., 113, 97-120, doi:10.1016/S0168-1923(02)00104-1.

Le Quéré, C., et al. (2009), Trends in the sources and sinks of carbon dioxide, Nat. Geosci., 2, 831-836, doi:10.1038/ngeo689.

Lewicki, J. L., and S. L. Brantley (2000), $\mathrm{CO}_{2}$ degassing along the San Andreas fault, Parkfield, California, Geophys. Res. Lett., 27, 5-8, doi:10.1029/1999GL008380.

Maestre, F. T., and J. Cortina (2006), Ecosystem structure and soil-surface conditions drive the variability in the foliar $\delta^{13} \mathrm{C}$ and $\delta^{15} \mathrm{~N}$ of Stipa tenacissima in semiarid Mediterranean steppes, Ecol. Res., 21, 44-53, doi:10.1007/s11284-005-0091-4.

Martín, J. M., J. C. Braga, J. Aguirre, and Á. Puga-Bernabéu (2009), History and evolution of the North-Betic Strait (Prebetic Zone, Betic Cordillera): A narrow, early Tortonian, tidal-dominated, Atlantic-Mediterranean marine passage, Sediment. Geol., 216, 80-90, doi:10.1016/ j.sedgeo.2009.01.005.

Mook, W. G., J. C. Bommerson, and W. H. Staverman (1974), Carbon isotope fractionation between bicarbonate and gaseous carbon dioxide, Earth Planet. Sci. Lett., 22, 169-176, doi:10.1016/0012-821X(74) 90078-8

Mörner, N. A., and G. Etiope (2002), Carbon degassing from the lithosphere, Global Planet. Change, 33, 185-203, doi:10.1016/S0921-8181 (02)00070-X.

Oldenburg, C. M., J. L. Lewicki, and R. P. Happle (2003), Near-surface monitoring strategies for geologic carbon dioxide storage verification, LBNL Pap. 54089, Lawrence Berkeley Natl. Lab., Berkeley, Calif.
Oyonarte, C., A. Rey, J. Medeiros, I. Miralles, and P. Escribano (2012), The use of soil respiration as an ecological indicator in arid ecosystems of the SE of Spain: Spatial variability and controlling factors, Ecol. Indic., 14, 40-49, doi:10.1016/j.ecolind.2011.08.013.

Pan, Y., et al. (2011), A large and persistent carbon sink in the world's forests, Science, 11, 787-791.

Pataki, D. E., J. R. Ehleringer, L. B. Flanagan, D. Yakir, D. R. Bowling, C. J. Still, N. Buchmann, J. O. Kaplan, and J. A. Berry (2003), The application and interpretation of Keeling plots in terrestrial carbon cycle research, Global Biogeochem. Cycles, 17(1), 1022, doi:10.1029/ $2001 \mathrm{~GB} 001850$

Pérez, N. M., S. Nakal, H. Wakita, J. F. Albert-Beltrán, and R. Redondo (1996), Preliminary results on ${ }^{3} \mathrm{He} /{ }^{4} \mathrm{He}$ ratios in terrestrial fluids from Iberian Peninsula: Seismotectonics and neotectonic implications, Geogaceta, 20,830-833.

Raich, J. W., and A. Tufekcioglu (2000), Vegetation and soil respiration: Correlations and controls, Biogeochemistry, 48, 71-90, doi:10.1023/ A:1006112000616.

Reichstein, M., et al. (2005), On the separation of net ecosystem exchange into assimilation and ecosystem respiration: Review and improved algorithm, Global Change Biol., 11, 1424-1439, doi:10.1111/j.1365-2486. 2005.001002.x.

Rey, A., E. Pegoraro, and P. G. Jarvis (2008), Carbon mineralization rates at different soil depths across a network of European forest sites (FORCAST), Eur. J. Soil Sci., 59, 1049-1062, doi:10.1111/j.1365-2389. 2008.01065.X

Rey, A., E. Pegoraro, C. Oyonarte, A. Were, P. Escribano, and J. Raimundo (2011), Impact $\mathrm{f}$ land degradation on soil respiration in a steppe ecosystem in the SE of Spain, Soil Biol. Biochem., 43, 393-403, doi:10.1016/ j.soilbio.2010.11.007.

Rey, A., L. Belelli-Marchesini, A. Were, P. Serrano, G. Etiope, D. Papale, F. Domingo, and E. Pegoraro (2012), Wind as the main driver of net ecosystem carbon balance of a semiarid steppe ecosystem in the SE of Spain, Global Change Biol., 18, 539-554, doi:10.1111/j.1365-2486. 2011.02534.x.

Sano, Y., and B. Marty (1995), Origin of carbon in fumarolic gas from island arc, Chem. Geol., 119, 265-274, doi:10.1016/0009-2541(94)00097-R.

Sano, Y., and H. Wakita (1988), Precise Measurement of Helium-Isotopes in Terrestrial Gases, Bull. Chem. Soc. Jpn., 61, 1153-1157, doi:10.1246/ bcsj.61.1153.

Sanz de Galdeano, C. (1990), Geologic evolution of the Betic Cordilleras in the western Mediterranean, Miocene to the present, Tectonophysics, 172, 107-119, doi:10.1016/0040-1951(90)90062-D.

Sanz de Galdeano, C., C. López-Casado, J. Delgado, and M. A. Peinado (1995), Shallow seismicity and active faults in the Betic Cordillera. A preliminary approach to seismic sources associated with specific faults, Tectonophys., 248, 293-302, doi:10.1016/0040-1951(94)00279-I.

Serrano-Ortiz, P., F. Domingo, A. Cazorla, A. Were, S. Cuerva, L. Villagarcía, L. Alados-Arboledas, and A. S. Kowalski (2009), Interannual CO exchange of a sparse Mediterranean shrubland on a carbonaceous substrate, J. Geophys. Res., 114, G04015, doi:10.1029/2009JG000983.

Takahashi, Y., and N. Liang (2007), Development of chamber-based sampling technique for determination of carbon stable isotope ratio of soil respired $\mathrm{CO}_{2}$ and evaluation of influence of $\mathrm{CO}_{2}$ enrichment in chamber headspace, Geochem. J., 41, 493-500, doi:10.2343/geochemj.41.493.

U.S. Environmental Protection Agency (EPA) (2010), Methane and nitrous oxide emissions from natural sources, EPA Rep. 430-R-10-001, Off. of Atmos. Programs, Washington, D. C.

U.S. Environmental Protection Agency (EPA) (2012), Inventory of U.S. greenhouse gas emissions and sinks: 1990-2010, EPA Rep. 430-R-12001, Off. of Atmos. Programs, Washington, D. C.

Werner, C., and S. Brantley (2003), $\mathrm{CO}_{2}$ emissions from the Yellowstone volcanic system, Geochem. Geophys. Geosyst., 4, 1061, doi:10.1029/ $2002 \mathrm{GC} 000473$.

Werner, C., and A. Gessler (2011), Diel variations in the carbon isotope composition of respired $\mathrm{CO}_{2}$ and associated carbon sources: A review of dynamics and mechanisms, Biogeosciences, 8, 2437-2459, doi:10.5194/ bg-8-2437-2011.

Williams-Jones, G., J. Stix, M. Heiligmann, A. Charland, B. Sherwood, L. N. Arner, G. Garzón, J. Barquero, and E. Fernandez (2000), A model of diffuse degassing at three subduction-related volcanoes, Bull. Volcanol., 62, 130-142, doi:10.1007/s004450000075. 